\title{
Nuclear factor of activated T-cell isoform expression and regulation in human myometrium

\author{
Evonne C. Chin-Smith ${ }^{1}$, Frances R. Willey ${ }^{1}$, Donna M. Slater ${ }^{2}$, Michael J. Taggart ${ }^{3}$ and Rachel M. Tribe ${ }^{1 *}$
}

\begin{abstract}
Background: During pregnancy, myometrial gene and protein expression is tightly regulated to accommodate fetal growth, promote quiescence and ultimately prepare for the onset of labour. It is proposed that changes in calcium signalling, may contribute to regulating gene expression and that nuclear factor of activated T-cell (NFAT) transcription factors (isoforms (1-c4) may be involved. Currently, there is little information regarding NFAT expression and regulation in myometrium.

Methods: This study examined NFAT isoform mRNA expression in human myometrial tissue and cells from pregnant women using quantitative PCR. The effects of the $\mathrm{Ca}^{2+}$ ionophore A23187 and in vitro stretch (25\% elongation, static strain; Flexercell FX-4000 Tension System) on NFAT expression were determined in cultured human myometrial cells.
\end{abstract}

Results: Human myometrial tissue and cultured cells expressed NFATc1-c4 mRNA. NFATc2 gene expression in cultured cells was increased in response to $6 \mathrm{~h}$ stretch (11.5 fold, $P<0.001, n=6)$ and calcium ionophore (A23187, $5 \mu \mathrm{M})$ treatment $(20.6$ fold, $P<0.001, n=6)$. This response to stretch was significantly reduced $(90 \%, P<0.001, n=10)$ in the presence of an intracellular calcium chelator, BAPTA-AM $(20 \mu \mathrm{M})$.

Conclusions: These data suggest that NFATC2 expression is regulated by intracellular calcium and in vitro stretch, and that the stretch response in human myometrial cells is dependent upon intracellular calcium signalling pathways. Our findings indicate a potentially unique role for NFATc2 in mediating stretch-induced gene expression per se and warrant further exploration in relation to the mechanisms promoting uterine smooth muscle growth in early pregnancy and/or labour.

Keywords: A23187, Uterine smooth muscle, NFAT, Stretch, Transcription factors

\section{Background}

It is widely accepted that a rise in the availability of intracellular $\mathrm{Ca}^{2+}$, through the up-regulation of calcium influx and release pathways, underpins the development of forceful uterine contractions during labour [1-3]. However, there is little understanding of how changes in calcium signalling in response to mechanical signals could drive changes in gene and protein expression in myometrium during early pregnancy or prior to labour to influence uterine development, growth and/or contractility.

\footnotetext{
* Correspondence: rachel.tribe@kcl.ac.uk

Evonne C Chin-Smith and Frances R Willey are joint first authors on this work.

'Division of Women's Health, King's College London, Women's Health Academic Centre KHP, St Thomas' Hospital, 10th Floor, North Wing, Westminster Bridge Road, London SE1 7EH, UK

Full list of author information is available at the end of the article
}

Over the course of pregnancy, the myometrium must grow in size to accommodate the fetus and amniotic fluid, resulting in a 20-fold expansion in size and at term must become contractile in preparation for labour [4]. Animal models have shown that myometrial cells undergo a program of differentiation phases consisting of an early proliferative phase during which cells are hyperplastic, an intermediate synthetic phase consisting of cell hypertrophy, a third phase at around mid-gestation during which myometrial cells stop growing, contractile mechanisms are up-regulated and pro-quiescent factors are down-regulated and a final phase at the end of gestation in which cells switch to being highly active and committed to labour [5-8]. Studies that have measured uterine weight at opportune times in human pregnancy indicate that the human myometrium undergoes a period of rapid growth 
between the non pregnant state and the $20^{\text {th }}$ week of pregnancy and subsequently, and in contrast to animals, continues to grow at a slower rate until close to term $[9,10]$.

The link between exogenous signals such as mechanical stretch and endocrine signals and intracellular events to drive human uterine smooth muscle cell hyperplasia in early-mid pregnancy and hypertrophy in human myometrium are not clearly defined. In other cell types and smooth muscles, however, intracellular calcium signals are well known to regulate gene expression and growth through downstream activation and modulation of transcription factors [11-14] but in human pregnant myometrium, there is little documented about the role of $\mathrm{Ca}^{2+}$-sensitive transcription factors.

An important family of $\mathrm{Ca}^{2+}$-sensitive transcription factors are the nuclear factor of activated T-cells (NFAT) which consist of 4 isoforms, nuclear factor of activated T-cells, cytoplasmic, calcineurin-dependent 1 (NFATc1), NFATc2, NFATc3 and NFATc4. This group of transcription factors also include the $\mathrm{Ca}^{2+}$ /calcineurin-insensitive NFAT5. NFAT protein activation is initiated by the phosphatase calcineurin, which is controlled by $\mathrm{Ca}^{2+}$ and calmodulin $[15,16]$. Activated calcineurin dephosphorylates cytoplasmic NFAT proteins allowing rapid translocation of NFAT to the nucleus $[16,17]$ and binding to DNA. Other nucleoproteins can bind cooperatively with NFAT, including members of the AP-1 transcription factor [18].

NFAT transcription factors were originally identified to play a role in immune cell function, but have since been shown to be present in smooth muscle cell types, including human myometrial artery smooth muscle [19], mouse ileal smooth muscle [20] and mouse cerebral artery smooth muscle [21] and have been implicated in the regulation of genes that control cell cycle progression, cell development, cell differentiation and angiogenesis [22-26].

There are very few reports of NFAT expression in relation to myometrium. Tabata et al. [27] identified gestational changes in NFAT isoform c1, c3 and c4 mRNA expression in pregnant mouse uterus and more recently; Pont et al. [28] demonstrated oxytocin-induced NFAT nuclear translocation which mirrored pulses of oxytocin in a frequency-dependent manner in non-pregnant human myometrial cells.

The aim of this study was to identify NFAT isoforms in pregnant human myometrial tissue and primary myometrial cells. The regulation of NFAT mRNA expression by intracellular calcium was also investigated, as there are reports in other cell types that NFATc1 gene expression is up-regulated by rises in intracellular $\mathrm{Ca}^{2+}$ [29-34]. As mechanical strain/stretch, pregnancy and labour associated stimulus for uterine smooth muscle hyperplasia and hypertrophy may increase intracellular calcium [35-38] we also explored the effect of in vitro stretch on myometrial NFAT expression.

\section{Methods \\ Subjects}

Human myometrial biopsies were obtained at Caesarean section with informed written consent and institutional Ethics Committee approval (Guy's and St Thomas' Hospital NHS Trusts, London, UK; Office of Medical Bioethics, University of Calgary). Biopsies from the upper edge of the lower segment incision were obtained from pregnant women at the time of elective caesarean section (at term prior to labour), none of the women had underlying medical conditions (reasons for elective caesarean section at 37-40 weeks were: maternal request, breech presentation, previous caesarean section, fetal cardiac anomaly detected antenatally, stress incontinence, previous $3^{\text {rd }}$ degree tear or placenta praevia). In addition, lower segment human myometrium was also obtained from four groups of women at the time of caesarean section (LSCS) under the conditions of preterm no labour (PTNL; $29.2 \pm 1.7$ weeks', myometrium samples from $n=5$ women, reasons for elective caesarean section were intrauterine growth restriction or preeclampsia/pregnancy induced hypertension), preterm with labour (PTL; $30.0 \pm 2.1$ weeks', samples from $n=4$ women, reasons for caesarean section were breech presentation, previous caesarean section and increased fetal heart rate detected during labour), term no labour (TNL; $39.5 \pm$ 0.4 weeks', samples from $n=6$ women, reason for caesarean section was previous caesarean section or breech) and term with labour (TL; $39.1 \pm 0.6$ weeks', samples from $n=6$ women, reasons for caesarean section were presented in early labour and elected to have section, failure to progress and/or fetal distress in labour). Whole myometrial tissue was either snap frozen and stored at $-80^{\circ} \mathrm{C}$ or used immediately for cell culture.

\section{Cell culture}

Myometrial cells were dispersed enzymatically from tissue biopsies as described previously from term non-labouring (TNL) women [39]. Briefly, small segments of myometrium were dissected and chopped into $1-2 \mathrm{~mm}^{3}$ pieces and incubated for 30-40 $\mathrm{min}$ in Dulbeccos modified Eagles medium (DMEM) containing $1 \mathrm{mg} / \mathrm{ml}$ collagenase $1 \mathrm{~A}, 1 \mathrm{mg} / \mathrm{ml}$ collagenase XI plus $0.1 \%$ bovine serum albumin (BSA), penicillin (50 units $/ \mathrm{ml}$ ), and streptomycin $(50 \mathrm{mg} / \mathrm{ml})$. Cells were dislodged using a Pasteur pipette and then filtered through a $45 \mu \mathrm{m}$ sterile filter, and washed twice in DMEM containing $10 \%$ fetal calf serum (FCS) by centrifugation $(450 \times g 5 \mathrm{~min})$. The cell pellet was suspended in DMEM supplemented with $10 \%$ FCS, penicillin (25 units $/ \mathrm{ml}$ ), and streptomycin $(25 \mathrm{mg} / \mathrm{ml})$. Primary myocytes were seeded in T25 culture flasks and incubated at $37{ }^{\circ} \mathrm{C}$ in a humidified atmosphere of $95 \%$ air $/ 5 \% \mathrm{CO}_{2}$. 
Routine immunofluorescent labeling of cells with alphaactin and calponin monoclonal antibodies was routinely performed to verify the purity of myocyte cultures. After the first 2 days of culture, media was replaced with DMEM supplemented with $5 \%$ FCS, penicillin (25 units $/ \mathrm{ml}$ ), and streptomycin $(25 \mathrm{mg} / \mathrm{ml})$. The medium was changed every 2 days until cells were $\sim 80 \%$ confluent. Cells were used for experimentation at passage 2 (P2) in order to have enough material for in vitro the stretch protocol.

\section{Exposure of human myometrial cells to $\mathrm{A} 23187 \mathrm{Ca}^{2+}$ ionophore treatment}

Human myometrial cells (P2) were cultured in six well culture plates in $3 \mathrm{ml}$ DMEM plus $5 \%$ FCS (Corning) until approximately $80 \%$ confluent. Following replenishment of media ( $24 \mathrm{~h}$ prior to experimentation, $5 \% \mathrm{FCS}$ ), cells were exposed to A23187 $\mathrm{Ca}^{2+}$ ionophore $(5 \mu \mathrm{M}$, Sigma-Aldrich, UK) or vehicle control (0.1\% dimethyl sulfoxide, Sigma-Aldrich, Gillingham, UK) for 6 or $14 \mathrm{~h}$ at $37{ }^{\circ} \mathrm{C}$ in a humidified atmosphere of $95 \%$ air/5\% $\mathrm{CO}_{2}$. At the end of the experiment, cells were rinsed with phosphate-buffered saline (PBS) and collected for RNA/protein extraction.

\section{Exposure of myometrial cells to tonic mechanical strain}

A method similar to that used in the present has been described previously by us and others [40, 41]. Pregnant human myometrial cells (P2) were cultured in six well flexible-bottom culture plates pre-coated with collagen type I (Flexcell International Corp., Hillsborough, USA) in $3 \mathrm{ml}$ DMEM plus $5 \%$ FCS until approximately $80 \%$ confluent. Media was replaced 24 hours before cells were subjected to $25 \%$ tonic mechanical stretch for $6 \mathrm{~h}$ using a strain unit (Flexercell FX-4000 Tension system, Flexcell International Corp., Hillsborough, USA) housed in a cell culture incubator $\left(37{ }^{\circ} \mathrm{C}, 95 \%\right.$ air, $\left.5 \% \mathrm{CO}_{2}\right)$. Time matched control cells were grown on the same flexible-bottomed culture plates, but were not stretched. In order to test the impact of buffering of intracellular $\mathrm{Ca}^{2+}$ whilst stretching, cells were pre-incubated for $1 \mathrm{~h}$ with BAPTA-AM $(20 \mu \mathrm{M}$, Sigma-Aldrich, Gillingham, UK) or vehicle control ( $0.1 \%$ dimethyl sulfoxide) before commencement of the $6 \mathrm{~h}$ tonic mechanical strain protocol. Subsequent to treatments, cells were washed with PBS and RNA extracted.

\section{RNA isolation from human myometrial tissue and human myometrial cells}

Total RNA was extracted from human myometrial tissue from term non-labouring (TNL) women $(\sim 30 \mathrm{mg}$ per sample) was homogenized using a TissueLyser (Qiagen, Crawley, UK) in Trizol $^{\circ}$ (Invitrogen, Paisley, UK) as per manufacturer's recommendations. RNA was extracted from cultured myometrial cells using the RNeasy mini kit (Qiagen, UK) according to the manufacturer's instructions. RNA samples were quantified using a Thermo Scientific NanoDrop ND-1000 spectrophotometer (Labtech, International Ltd, East Sussex, UK). The absorbance of each sample at $260 \mathrm{~nm}$ was used to calculate RNA concentration and an optical density 260/ 280 ratio was calculated to determine RNA purity. An OD 260/280 ratio of more than 1.8 was considered acceptable [42].

\section{Quantitative real-time PCR}

cDNA was synthesised from 500 ng RNA using $0.25 \mu \mathrm{g}$ random hexanucleotide primers (Promega, Southampton, UK) and 200 IU Superscript III (Invitrogen, Paisley, UK). Quantitative real-time PCR was performed with the use of SYBR Green chemistry (Bioline, London, UK) and a RotorGene 6000 Sequence Detector (Qiagen, Crawley, UK) using primer sets as listed in Table I. The PCR cycling conditions were as follows: an initial denaturation step of $95^{\circ} \mathrm{C}$ for $10 \mathrm{~min}$, then 45 cycles of a programme consisting of denaturation $\left(95{ }^{\circ} \mathrm{C}, 15 \mathrm{~s}\right)$, annealing $\left(60{ }^{\circ} \mathrm{C}, 30 \mathrm{~s}\right)$ and extension $\left(72{ }^{\circ} \mathrm{C}, 20 \mathrm{~s}\right)$. Melt curve analysis confirmed a single product, and all products were sequenced to confirm identity. Negative reverse transcription reactions were used routinely to assess genomic DNA contamination. Test samples were run in duplicate in parallel with cDNA standards of known gene copy number abundance ( $10^{6}$ to $10^{1}$ copies). Cycle threshold values were used for analysis and abundance data was obtained for test samples by the generation of a standard curve based on the quantified cDNA. Abundance data for NFAT isoform expression for cell studies, Figures 1, 2, 4 and 5 were expressed relative to the geometric mean of a panel of housekeepers (glyceraldehyde 3-phosphate dehydrogenase (GAPDH), $\beta$-actin and $\beta-2$ microglobulin) as determined by GeNorm software [43] and for tissues only GAPDH was used due to limited cDNA availability and previous assessment which showed GAPDH was the most stable housekeeper for tissue analysis (Fig. 6). All data were $\log _{10}$ transformed.

\section{Preparation of whole cell protein lysates}

Myometrial whole cell lysates were prepared by removing culture medium and rising twice with ice-cold PBS. The cells were then aspirated to dryness and $100 \mu \mathrm{l}$ of lysis buffer (10 mM of Hepes- $\mathrm{KOH}$ [pH 7], $1 \mathrm{mM}$ of dithiothreitol, $1 \%$ nonident-P40, and protease-inhibitor cocktail [COMPLETE tablets; Boehringer-Mannheim Biochemicals, Lewes, Sussex, U.K.]) was added to each well and incubated on ice for $5 \mathrm{~min}$. Cells were then scraped and the lysate removed and placed in to a $1.5 \mathrm{ml}$ microfuge tube and centrifuged for 1 minute at $13,000 \mathrm{rpm}$ to remove any cell debris. Tissue and whole cell lysate protein content was quantified using a Thermo 


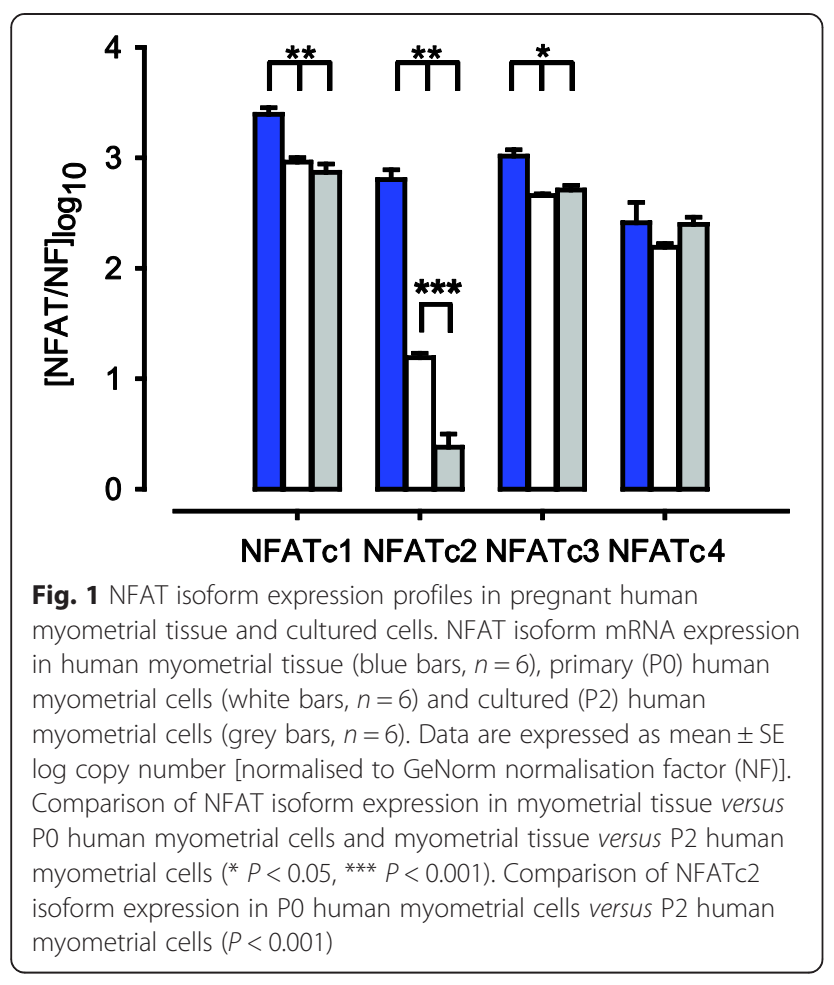

Fig. 1 NFAT isoform expression profiles in pregnant human myometrial tissue and cultured cells. NFAT isoform mRNA expression in human myometrial tissue (blue bars, $n=6$ ), primary (P0) human myometrial cells (white bars, $n=6$ ) and cultured (P2) human Comparison of NFAT isoform expression in myometrial tissue versus P0 human myometrial cells and myometrial tissue versus P2 human myometrial cells (* $P<0.05 * * * P<0.001)$. Comparison of NFATC2 myometrial cells $(P<0.001)$
Scientific NanoDrop ND-1000 spectrophotometer. Lysates were then diluted $1: 1$ with $\times 2$ Laemmli sample buffer (Sigma) then boiled at $95{ }^{\circ} \mathrm{C}$ for $5 \mathrm{~min}$. Samples were then stored at $-20{ }^{\circ} \mathrm{C}$ until required, when they were thawed, then re-boiled for $5 \mathrm{~min}$ at $95{ }^{\circ} \mathrm{C}$ and centrifuged at $12470 \mathrm{~g}$ for $1 \mathrm{~min}$ prior to electrophoresis.

\section{SDS-PAGE and Western Immunoblotting}

Whole cell lysate proteins were separated using $10 \%$ Tris-Glycine precast gels (Invitrogen) using the XCell SureLock ${ }^{\text {ma }}$ Mini-Cell system (Invitrogen). Following electrophoresis, proteins were transferred to Immobilion ${ }^{\text {Th }}-\mathrm{P}$ transfer membrane (Millipore) using the XCell SureLock ${ }^{\mathrm{m}}$ Mini-Cell blotting module wet transfer blotting system. After transfer of proteins to the membrane, non-specific sites were blocked by soaking the membrane in $100 \%$ methanol for $10 \mathrm{~s}$ and then allowing the membrane to dry completely for approximately $15 \mathrm{~min}$. Membranes were then incubated for at least $5 \mathrm{~h}$ with maximum speed of agitation at room temperature or overnight at $4{ }^{\circ} \mathrm{C}$ with the appropriate NFATc2 primary antibody (Abcam: AB2722) diluted 1:1000 or $\beta$-actin (Abcam: AB6276) diluted 1:5000 in tris-buffered saline with tween (TBS-T: $50 \mathrm{mM}$ Tris, $150 \mathrm{mM} \mathrm{NaCl}, 0.2 \%$ (v/v) Tween-20, $\mathrm{pH}$ 7.4) containing $10 \%(\mathrm{w} / \mathrm{v})$ BSA. Membranes were then washed for $3 \times 20 \mathrm{~min}$ in TBS-T. Following the incubation of the membrane in a 1:10,000 dilution in TBS-T of horseradish peroxidase (HRP)-conjugated goat antimouse secondary antibody (BD Pharmigen) for $45 \mathrm{~min}$,

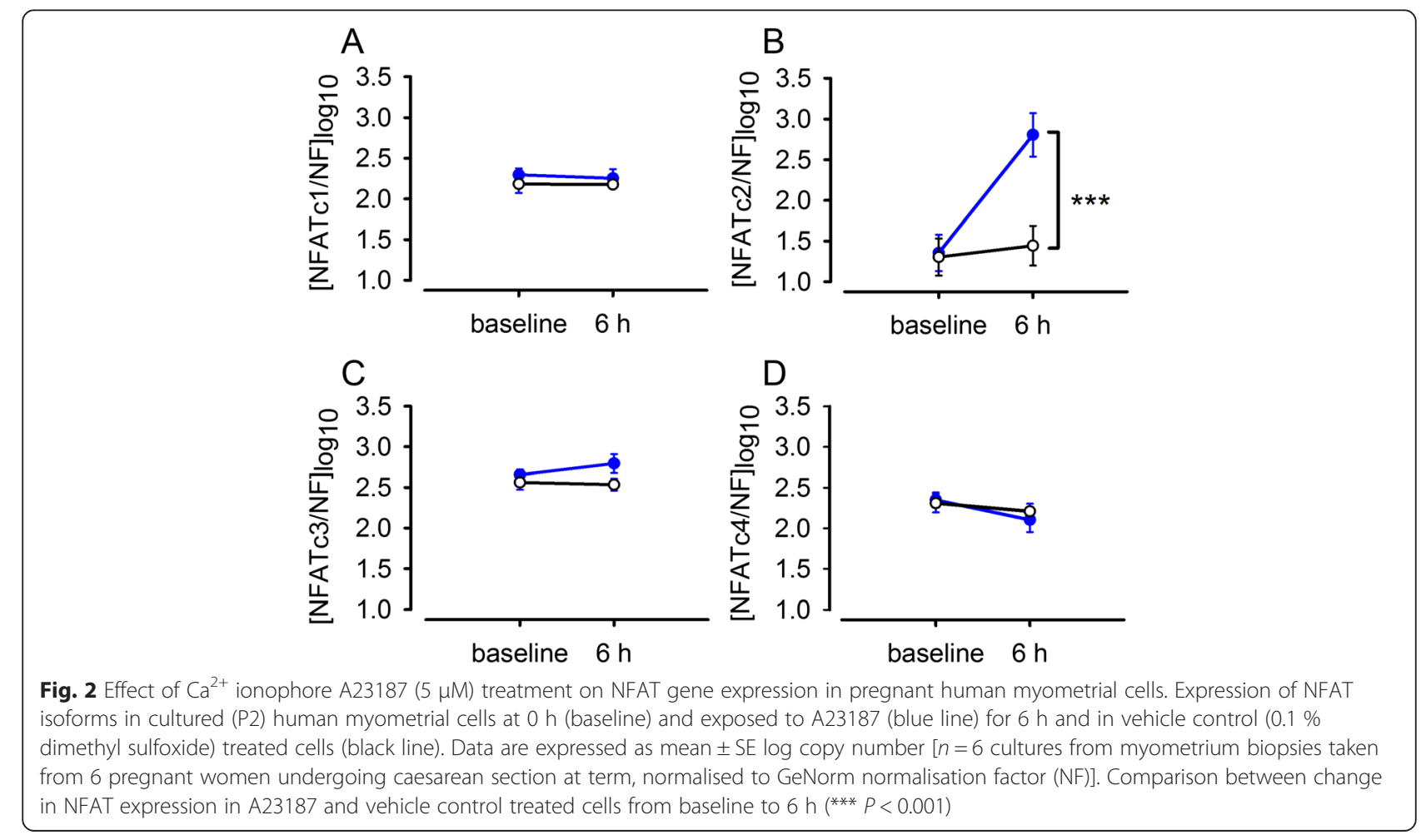


the membrane was washed a further $3 \times 20$ minutes in TBS-T. Immunoreactive proteins were visualised using enhanced chemiluminescence $\left(\mathrm{ECL}^{\mathrm{Tm}}\right)$ (Amersham) according to the manufacturer's instructions. Densitometric quantification of immunoreactive bands was carried out using BioRad Molecular Quantity One software, version 4.4.0. To verify equal protein loading, blots were also probed with $\beta$-actin antibody.

\section{Statistical analysis}

Data were analysed using Stata 10.0 (Stata Corp., College Station, USA). Differences between NFAT isoform expression in tissue and cells were assessed using linear regression. Results were expressed as ratios of the group means with $95 \%$ confidence intervals; mean gene expression \pm SEM is displayed graphically. The impact of experimental interventions on gene expression in human myometrial cells over time was estimated using linear regression on the log-copy number with a fixed subject effect to adjust for clustering and interaction tests were carried out where necessary. Mean fold changes over time in gene expression are presented in the text with $95 \%$ confidence intervals; mean gene expression \pm SEM at each time point is displayed graphically. Significance for all data was taken at $P<0.05$. ' $n$ ' refers to the total number of cell cultures (each originating from a biopsy from a different subject).

\section{Results}

NFAT mRNA expression in human myometrial tissue, primary human (P0) myometrial cells and cultured (P2) human myometrial cells

NFAT mRNA for all isoforms (c1-c4) was detected in human myometrial tissue $(n=6)$. NFAT isoforms c1-c4 were also expressed in P0 $(n=6)$ and P2 $(n=6)$ human myometrial cells, but NFATc1, NFATc2 and NFATc3 expression was suppressed in P0 and P2 human myometrial cells compared to myometrial tissue. NFATc2 expression was lower in P2 compared to P0 cells (95\% CI: 71.4 to $91.7, P<0.001$ ). (Fig. 1 ).

\section{Effect of $\mathrm{Ca}^{2+}$ ionophore A23187 treatment on NFAT gene} expression and protein in human myometrial cells Application of the $\mathrm{Ca}^{2+}$ ionophore A23187 caused a 20.6 times (95 \% CI: 7.6 to $55.6, P<0.001, n=6$ ) increase in NFATc2 gene expression over $6 \mathrm{~h}$ compared to vehicle control (Fig. 2). There was no significant effect of $\mathrm{Ca}^{2+}$ ionophore A23187 treatment on NFATc1, NFATc3 or NFATc4 expression. Incubation of human myometrial cells with $\mathrm{Ca}^{2+}$ ionophore A23187 for $14 \mathrm{~h}$ significantly increased NFATc2 protein expression $(p<0.05, n=6)$ (Fig. 3).

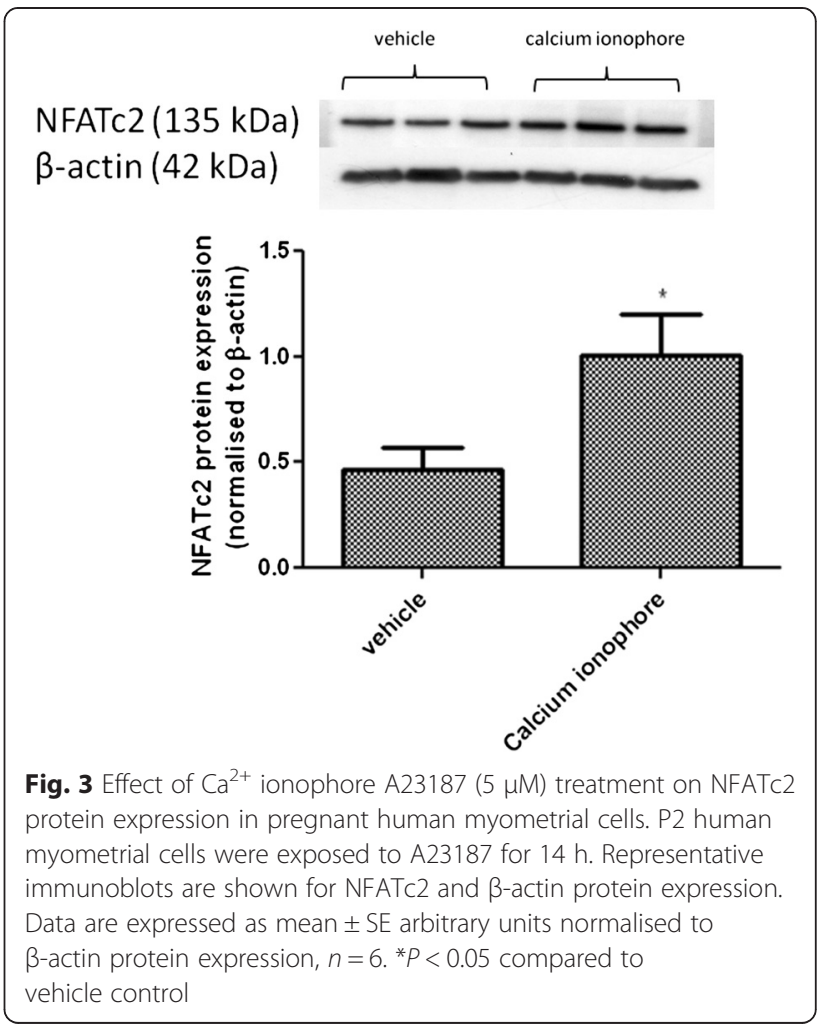

Effect of in vitro stretch on NFAT gene expression in human myometrial cells

In vitro stretch of cultured (P2) human myometrial cells caused an 11.5 times (95 \% CI: 4.3 to $30.9, P<0.001, n=6$ ) increase in NFATc2 gene expression over $6 \mathrm{~h}$ compared to non-stretched cells (Fig. 4). There was no effect of in vitro stretch on the expression of any other of the NFAT isoforms.

\section{Impact of BAPTA-AM on NFATc2 gene expression in stretched human myometrial cells}

There was a small effect (1.9 fold, $95 \% \mathrm{CI}: 1.3$ to $2.7, P<$ $0.05, n=10)$ of BAPTA-AM on NFATc2 expression in non-stretched cells (change from $t=0 \mathrm{~h}$ to $t=6 \mathrm{~h}$ ) but not in the vehicle control (Fig. 5), but there was no difference between absolute NFATc2 mRNA expression in BAPTAAM treated cells compared to cells exposed to vehicle at the 6 hour time point. NFATc2 gene expression was significantly increased 11.0 times (95 \% CI: 4.6 to $26.4, P<0.001$, $n=10)$ in stretched cells, but there was a $90 \%$ reduction (95\% CI: $72.3 \%$ to $96.4 \%, P<0.001, n=10$ ) in the effect of stretch on NFATc2 gene expression in the presence of BAPTA-AM.

\section{NFATc2 mRNA expression in preterm and term human} myometrial tissue

NFATc2 mRNA expression was detected in myometrial tissues taken from women delivering preterm and term 

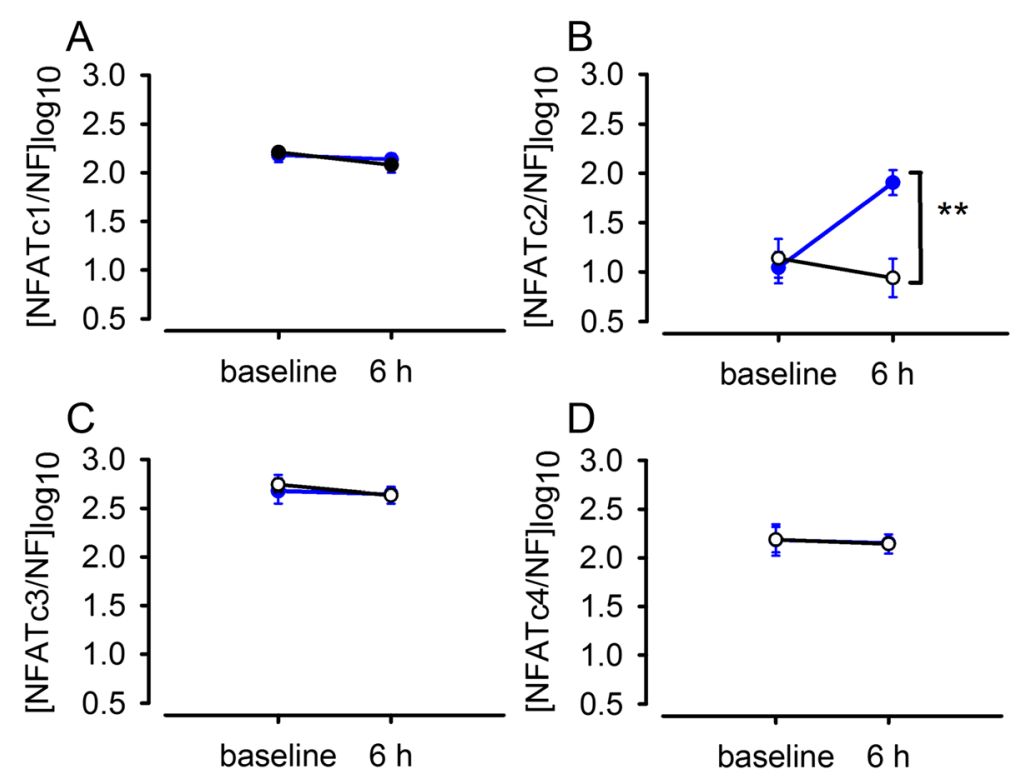

Fig. 4 Effect of in vitro stretch on NFAT gene expression in pregnant human myometrial cells. Expression of NFAT isoforms in cultured (P2) human myometrial cells at $0 \mathrm{~h}$ (baseline) and exposed to $25 \%$ in vitro strain (blue line) for $6 \mathrm{~h}$ and in non-stretched time-matched control cells (black line). Data are expressed as mean \pm SE log copy number $[n=6$, normalised to GeNorm normalisation factor (NF)]. Comparison between change in NFAT expression in stretched and non-stretched cells from baseline to $6 \mathrm{~h}\left({ }^{*} P<0.001\right)$
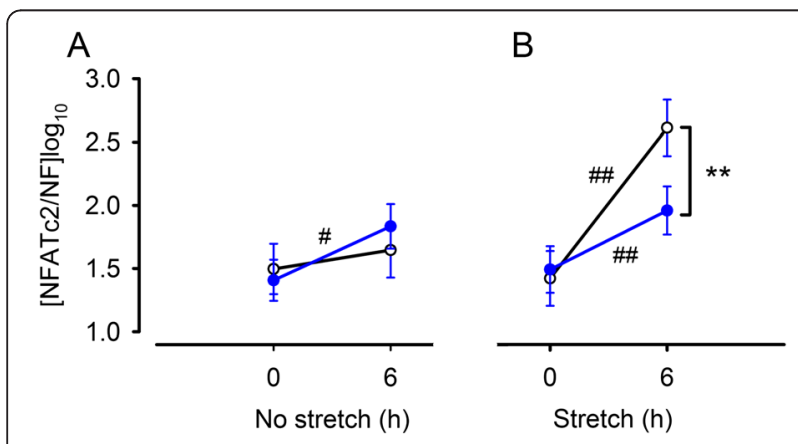

Fig. 5 Impact of BAPTA-AM on NFATc2 gene expression in cultured (P2) pregnant human myometrial cells during a $6 \mathrm{~h}$ stretch period. A) NFATc2 expression in non-stretched control cells ( $t=0$ to $t=6 \mathrm{~h}$ ) treated with BAPTA-AM $(20 \mu \mathrm{M})$ (blue line) or vehicle control $(0.1 \%$ dimethyl sulfoxide) (black line). B) NFATc2 expression in $6 \mathrm{~h}$ stretched (25\% static strain) cells ( $\mathrm{t}=0$ to $\mathrm{t}=6 \mathrm{~h}$ ) treated with BAPTA-AM (blue line) or vehicle control (black line). Data are expressed as mean \pm SE log copy number $[n=10$, normalised to GeNorm normalisation factor (NF)]. In non-stretched cells there was a slight change in NFATC2 expression (\# $P<0.05$ ) from $\mathrm{t}=0 \mathrm{~h}$ to $\mathrm{t}=6 \mathrm{~h}$ in BAPTA-AM treated cells, but there was no significant difference in BAPTA-AM-treated versus vehicle control at $\mathrm{t}=6 \mathrm{~h}$. Both BAPTA-AM treated and vehicle control treated cells under stretch demonstrated a significant change in NFATc2 expression between $\mathrm{t}=0 \mathrm{~h}$ to $\mathrm{t}=6 \mathrm{~h}$ $(\# \#, P=0.001)$ but the effect of stretch was significantly greater in cells in the absence of BAPTA-AM (** $P<0.001)$ gestations. There was no significant difference in tissues taken from women prior to or during labour (Fig. 6).

\section{Discussion}

This study demonstrates the presence of mRNA for all $\mathrm{Ca}^{2+}$ /calcineurin-dependent NFAT isoforms c1-c4 in pregnant human myometrium and cultured cells. This is in good agreement with previously a published report of NFAT isoform expression in non-pregnant human myometrial cells [28]. However, the expression profile in human myometrial tissue contrasts with NFAT expression profiles in other smooth muscle tissue types, including human myometrial artery, mouse ileal smooth muscle and mouse cerebral artery smooth muscle in which NFATc2 has not been detected [19-21]. Moreover, although NFATc2 has been detected in smooth muscle from human and rat aorta [44-46] as well as human myometrial arteries after culture [19], the presence of NFATc2 in pregnant myometrial and cultured cells indicates a potentially important role for NFATc2 in human myometrium.

All four isoforms, NFATc1-4, were expressed in human myometrium tissue taken from women at term, but prior to labour onset. In contrast, cultured (P0) human myometrial cells displayed an altered NFAT mRNA expression profile compared to tissue, with NFATc1, c2 and c3 isoform expression significantly decreased in primary cells that were cultured in media containing $5 \%$ serum. NFATc1 and NFATc3 gene expression remained stable following a further period of culture (until P2), but NFATc2 expression decreased further. The differences between 


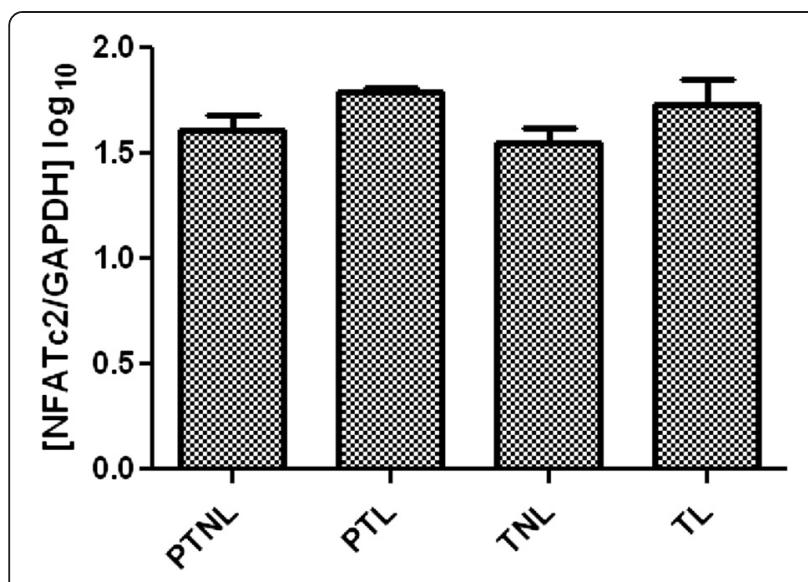

Fig. 6 Effect of gestation and labour on NFATc2 gene expression in human myometrial tissue. Data are expressed as mean \pm SE log copy number normalised to GAPDH. PTNL $=5, \mathrm{PTL}=4, \mathrm{TNL}=6, \mathrm{TL}=6$

tissue and primary cells NFATc expression levels could reflect the multicellular composition of myometrial tissue (e.g. immune cells, vascular cells etc.) but alternatively, the reduction in NFATc1, NFATc2 and NFATc3 gene expression is more likely to be due to phenotypic changes induced by the cell culture environment, and indicative that NFAT genes can be modulated in human myometrial cells. In our culture systems, cells are grown in the presence of $5 \%$ serum and receiving signals to promote hyperplasia, whereas in myometrial tissue at term cells are no longer dividing [8].

Interestingly, the human myometrium cell culture (P2) associated reduction in NFATc2 mRNA and protein expression was reversed by exposing the cells to myometrial cells to $\mathrm{Ca}^{2+}$ ionophore A23187. This is of interest as whilst NFATc1 has been previously demonstrated in immune cells to be susceptible to gene regulation, NFATc2 mRNA and it associated protein has only been found to be constitutively expressed in other tissues [30, 32, 34]. The explanation for this tissue-difference in isoform regulation is unclear due to limited information on NFAT promoter behaviour, but may reflect the dependency of NFATc1 and NFATc2 isoform mRNA regulation on additional factors that are specific to different cell types.

Our findings also show that prolonged in vitro mechanical stretch increased NFATc2 expression in vitro after $6 \mathrm{~h}$. This should be investigated to see whether it occurs at other time-points. Mechanical stretch has been implicated as a signal for mediating gene expression prior to labour onset; a mechanism for promoting contraction-associated proteins [47], but is also a signal for promoting cellular proliferation and growth [48-50]. Our data, therefore, could indicate a contribution of NFAT regulated transcription in human myometrial tissue during pregnancy particularly at earlier gestations when cells are proliferating (as per our in vitro stretch model). However, it is noted that in the small number of human myometrium tissues studied NFATc2 mRNA expression remained relatively stable at preterm and term gestations prior to and after labour onset, and so the involvement of this isoform in mediating changes associated with labour cannot be inferred without further study. It is interesting to note, that in mice NFATc1, 2 and 4 mRNAs have been reported to increase during pregnancy, although these data were obtained in an oxytocin receptor knock mouse model and the mRNA data were not quantified [27].

The observation that stretch induced changes in NFATc2 expression are suppressed by BAPTA-AM further implies that changes in intracellular calcium in response to stretch are important in this response. The impact on NFATc2 related protein expression still requires examination. Under non-stretch conditions, NFATc2 mRNA also increased slightly in the BAPTA-AM treated cells over time, but the expression level at $6 \mathrm{~h}$ was no different from the vehicle control at this time point, suggesting that the change was not biologically significant.

If these in vitro findings reflect responses in vivo then it is possible that uterine stretch (or other pregnancy associated stimuli that induce increases in $\mathrm{Ca}^{2+}$ ) could contribute to induction of NFATc2 expression and/or activation in myometrium in pregnant women. The translation and functional impact of these $\mathrm{Ca}^{2+}$ and/or stretch induced responses in myometrium now require further confirmation at the protein level. Ideally, studies looking at NFAT protein expression (and the other isoforms) and localisation in human tissues at different stages of gestation, and in cells, would shed further light other potential functional contributions NFTAc2 or other isoforms make in regulating uterine smooth muscle growth and contractility in pregnancy. We experienced difficulties with using antibodies to distinguish different NFATc isoforms (data not shown), which limited the scope of our study.

Investigations into the relationship of NFAT regulation with other important myometrial transcription factors, for example, NF-kB [51-55] and AP-1 would also be of interest given their reported interactions in other cell types [56-61].

\section{Conclusion}

In summary, the study presents novel data concerning NFAT mRNA expression and regulation by calcium in human myometrium. Our findings also indicate a potential role for NFATc2 in mediating stretch-induced gene expression per se. These warrant further exploration in relation to the mechanisms promoting myometrial cell proliferation/growth in pregnancy and contractility in prior to labour. In particular a more focussed study of NFATc2 protein function and translocation, using confocal imaging with immunohistochemistry and live cell calcium sensitive dyes, in response to different intracellular calcium and mechanical stretch signals is required. 


\section{Competing interests}

The authors declare that they have no competing interests.

\section{Authors' contributions}

ECS and FW designed and planned the study, analyzed and interpreted the data and drafted the manuscript. DMS collected myometrial tissue used in the study and assisted with data interpretation. MJT assisted with data interpretation. RMT planned the study, interpreted the data and drafted the manuscript. All authors read and approved the final manuscript.

\section{Acknowledgments}

We thank all the women who kindly participated in this study and Guy's and St Thomas' Hospital Trusts labour ward staff for myometrial sample collection. We are indebted to Mr Paul Seed for statistical assistance.

\section{Funding}

This work was supported by King's College London School of Medicine PhD studentship and funding from Tommy's Charity (Registered Charity number: 1060508).

\section{Author details}

${ }^{1}$ Division of Women's Health, King's College London, Women's Health Academic Centre KHP, St Thomas' Hospital, 10th Floor, North Wing, Westminster Bridge Road, London SE1 7EH, UK. Physiology and Pharmacology, Cumming School of Medicine, Alberta Children's Hospital Research Institute for Child and Maternal Health, University of Calgary, Alberta T2N 4 N1, Canada. ${ }^{3}$ Institute of Cellular Medicine, Newcastle University, Newcastle-upon-Tyne NE2 4HH, UK.

\section{Received: 7 January 2015 Accepted: 30 July 2015}

\section{Published online: 04 August 2015}

\section{References}

1. Word RA. Myosin phosphorylation and the control of myometrial contraction/relaxation. Semin Perinatol. 1995;19:3-14.

2. Dalrymple A, Slater DM, Poston L, Tribe RM. Physiological induction of transient receptor potential canonical proteins, calcium entry channels, in human myometrium: influence of pregnancy, labor, and interleukin-1 beta. J Clin Endocrinol Metab. 2004;89:1291-300.

3. Tribe RM, Moriarty P, Dalrymple A, Hassoni AA, Poston L. Interleukin-1beta induces calcium transients and enhances basal and store operated calcium entry in human myometrial smooth muscle. Biol Reprod. 2003;68:1842-9.

4. Nilsson UK. Different proliferative responses of Gi/o-protein-coupled receptors in human myometrial smooth muscle cells. a possible role of calcium. J Mol Neurosci. 1998;11:11-21.

5. Reynolds RM. The rate of uterine growth resulting from chronic distention. Anat Rec. 1937;69:281-6.

6. Salvatore CA. A cytological examination of uterine growth during pregnancy. Endocrinol. 1948;43:355-70.

7. Shynlova O, Tsui P, Jaffer S, Lye SJ. Integration of endocrine and mechanical signals in the regulation of myometrial functions during pregnancy and labour. Eur J Obstet Gynecol Reprod Biol. 2009;144 Suppl 1:S2-10.

8. Shynlova O, Kwong R, Lye SJ. Mechanical stretch regulates hypertrophic phenotype of the myometrium during pregnancy. Reproduction. 2010;139:247-53.

9. Hytten FE, Cheyne GA. The size and composition of the human pregnant uterus. J Obstet Gynaecol Br Commonw. 1969;76:400-3.

10. Brody S. Hormonal influence on the nucleic acid and protein contents of the human myometrium. Exp Cell Res. 1958;14:149-59.

11. Berridge MJ, Lipp P, Bootman MD. The versatility and universality of calcium signalling. Nat Rev Mol Cell Biol. 2000;1:11-21.

12. Fields RD, Lee PR, Cohen JE. Temporal integration of intracellular Ca2+ signaling networks in regulating gene expression by action potentials. Cell Calcium. 2005;37:433-42.

13. Ritchie MF, Zhou Y, Soboloff J. Transcriptional mechanisms regulating $\mathrm{Ca}(2+)$ homeostasis. Cell Calcium. 2011:49:314-21.

14. Kudryavtseva O, Aalkjaer C, Matchkov W. Vascular smooth muscle cell phenotype is defined by $\mathrm{Ca}^{2+-}$ dependent transcription factors. FEBS $\mathrm{J}$. 2013;280:5488-99.
15. Mellstrom B, Savignac M, Gomez-Villafuertes R, Naranjo JR. Ca2+-operated transcriptional networks: molecular mechanisms and in vivo models. Physiol Rev. 2013;88:421-49.

16. Li H, Rao A, Hogan PG. Interaction of calcineurin with substrates and targeting proteins. Trends Cell Biol. 2011;21:91-103.

17. Hogan PG, Chen L, Nardone J, Rao A. Transcriptional regulation by calcium, calcineurin, and NFAT. Genes Dev. 2003;17:2205-32.

18. Rao A, Luo C, Hogan PG. Transcription factors of the NFAT family: regulation and function. Annu Rev Immunol. 1997;15:707-47.

19. Nilsson LM, Sun ZW, Nilsson J, Nordstrom I, Chen YW, Molkentin JD, et al. Novel blocker of NFAT activation inhibits IL-6 production in human myometrial arteries and reduces vascular smooth muscle cell proliferation. Am J Physiol Cell Physiol. 2007;292:C1167-78.

20. Stevenson AS, Gomez MF, Hill-Eubanks DC, Nelson MT. NFAT4 movement in native smooth muscle. A role for differential $\mathrm{Ca}(2+)$ signaling. J Biol Chem. 2001;276:15018-24.

21. Gomez MF, Stevenson AS, Bonev AD, Hill-Eubanks DC, Nelson MT. Opposing actions of inositol 1,4,5-trisphosphate and ryanodine receptors on nuclear factor of activated T-cells regulation in smooth muscle. J Biol Chem. 2002;277:37756-64.

22. New 21, Wang C, Li JF, Zhao L, Liu J, Wan J, et al. Inhibition of SOC/Ca2 + /NFAT pathway is involved in the anti-proliferative effect of sildenafil on pulmonary artery smooth muscle cells. Respir Res. 2009;10:123.

23. Karpurapu M, Wang D, Van Quyen D, Kim TK, Kundumani-Sridharan V, Pulusani S, et al. Cyclin D1 is a bona fide target gene of NFATC1 and is sufficient in the mediation of injury-induced vascular wall remodeling. J Biol Chem. 2010;285:3510-23.

24. Bonnet S, Paulin R, Sutendra G, Dromparis P, Roy M, Watson KO, et al. Dehydroepiandrosterone reverses systemic vascular remodeling through the inhibition of the Akt/GSK3-\{beta\}/NFAT axis. Circulation. 2009;1 20:1231-40.

25. Pang $X$, Sun NL. Calcineurin-NFAT signaling is involved in phenylephrine-induced vascular smooth muscle cell proliferation. Acta Pharmacol Sin. 2009;30:537-44.

26. Benavides Damm T, Egli M. Calcium's role in mechanotransuction during muscle development. Cell Physiol Biochem. 2014;33:249-72.

27. Tabata C, Ogita K, Sato K, Nakamura H, Qing Z, Negoro H, et al. Calcineurin/NFAT pathway: a novel regulator of parturition. Am J Reprod Immunol. 2009;62:44-50.

28. Pont NA, McArdle CA, López-Bernal A. Oxytocin-stimulated NFAT transcriptional activiation in human myometrial cells. Mol Endocrinol. 2012;26:1743-56.

29. Amasaki Y, Miyatake S, Arai N, Arai K. Regulation of nuclear factor of activated T-cell family transcription factors during T-cell development in the thymus. J Allergy Clin Immunol. 2000;106:S1-9.

30. Lyakh L, Ghosh P, Rice NR. Expression of NFAT-family proteins in normal human T cells. Mol Cell Biol. 1997;17:2475-84.

31. Wu CC, Hsu SC, Shih HM, Lai MZ. Nuclear factor of activated T cells $\mathrm{c}$ is a target of p38 mitogen-activated protein kinase in T cells. Mol Cell Biol. 2003;23:6442-54

32. Masuda ES, Naito Y, Tokumitsu H, Campbell D, Saito F, Hannum C, et al. NFATx, a novel member of the nuclear factor of activated T cells family that is expressed predominantly in the thymus. Mol Cell Biol. 1995;15:2697-706.

33. Aramburu J, Azzoni L, Rao A, Perussia B. Activation and expression of the nuclear factors of activated T cells, NFATp and NFATc, in human natural killer cells: regulation upon CD16 ligand binding. J Exp Med. 1995;182:801-10.

34. Northrop JP, Ho SN, Chen L, Thomas DJ, Timmerman LA, Nolan GP, et al. NF-AT components define a family of transcription factors targeted in T-cell activation. Nature. 1994;369:497-502.

35. Sigurdson W, Ruknudin A, Sachs F. Calcium imaging of mechanically induced fluxes in tissue-cultured chick heart: role of stretch-activated ion channels. Am J Physiol. 1992;262:H1110-5.

36. Gotoh $\mathrm{H}$, Takahashi A. Mechanical stimuli induce intracellular calcium response in a subpopulation of cultured rat sensory neurons. Neuroscience. 1999;92:1323-9.

37. Chen Y, Simasko SM, Niggel J, Sigurdson WJ, Sachs F. Ca2+ uptake in GH3 cells during hypotonic swelling: the sensory role of stretch-activated ion channels. Am J Physiol. 1996;270:C1790-8.

38. Lansman JB, Hallam TJ, Rink TJ. Single stretch-activated ion channels in vascular endothelial cells as mechanotransducers? Nature. 1987;325:811-3.

39. Tribe RM, Moriarty P, Poston L. Calcium homeostatic pathways change with gestation in human myometrium. Biol Reprod. 2000;63:748-55. 
40. Dalrymple A, Mahn K, Poston L, Songu-Mize E, Tribe RM. Mechanical stretch regulates TRPC expression and calcium entry in human myometrial smooth muscle cells. Mol Hum Reprod. 2007;13:171-9.

41. Sooranna SR, Lee Y, Kim LU, Mohan AR, Bennett PR, Johnson MR. Mechanical stretch activates type 2 cyclooxygenase via activator protein-1 transcription factor in human myometrial cells. Mol Hum Reprod. 2004;10:109-13.

42. Fleige $S$, Pfaffl MW. RNA integrity and the effect on the real-time qRT-PCR performance. Mol Aspects Med. 2006;27:126-39.

43. Vandesompele J, De Preter K, Pattyn F, Poppe B, Van Roy N, De Paepe A et al. Accurate normalization of real-time quantitative RT-PCR data by geometric averaging of multiple internal control genes. Genome Biol. 2002;3(research):0034.1-0034.11.

44. Wada H, Hasegawa K, Morimoto T, Kakita T, Yanazume T, Abe M, et al Calcineurin-GATA-6 pathway is involved in smooth muscle-specific transcription. J Cell Biol. 2002;156:983-91.

45. Yellaturu CR, Ghosh SK, Rao RK, Jennings LK, Hassid A, Rao GN. A potential role for nuclear factor of activated T-cells in receptor tyrosine kinase and G-protein-coupled receptor agonist-induced cell proliferation. Biochem J. 2002;368:183-90.

46. Suzuki E, Nishimatsu H, Satonaka H, Walsh K, Goto A, Omata M, et al. Angiotensin II induces myocyte enhancer factor 2- and calcineurin/nuclear factor of activated $T$ cell-dependent transcriptional activation in vascular myocytes. Circ Res. 2002;90:1004-11.

47. Lye SJ, Mitchell J, Nashman N, Oldenhof A, Ou R, Shynlova O, et al. Role of mechanical signals in the onset of term and preterm labor. Front Horm Res. 2001;27:165-78.

48. Richard MN, Deniset JF, Kneesh AL, Blackwood D, Pierce GN. Mechanical stretching stimulates smooth muscle cell growth, nuclear protein import, and nuclear pore expression through mitogen-activated protein kinase activation. J Biol Chem. 2007;282:23081-8.

49. Kook SH, Lee HJ, Chung WT, Hwang IH, Lee SA, Kim BS, et al. Cyclic mechanical stretch stimulates the proliferation of $\mathrm{C} 2 \mathrm{C} 12$ myoblasts and inhibits their differentiation via prolonged activation of p38 MAPK. Mol Cells. 2008;25:479-86.

50. Wu Y, Zhang P, Dai Q, Yang X, Fu R, Jiang $L$, et al. Effect of mechanical stretch on the proliferation and differentiation of BMSCs from ovariectomized rate. Mol Cell Biochem. 2013;382:273-82.

51. Khanjani S, Kandola MK, Lindstrom TM, Sooranna SR, Melchionda M, Lee YS, et al. NF-kappaB regulates a cassette of immune/inflammatory genes in human pregnant myometrium at term. J Cell Mol Med. 2010;15:809-24.

52. Khanjani S, Terzidou V, Johnson MR, Bennett PR. NF-kB and AP-1 drive human myometrial IL8 expression. Mediators Inflamm. 2012. doi:10.1155/ 2012/504952.

53. Condon JC, Jeyasuria P, Faust JM, Mendelson CR. Surfactant protein secreted by the maturing mouse fetal lung acts as a hormone that signals the initiation of parturition. Proc Natl Acad Sci U S A. 2004;101:4978-83.

54. Condon JC, Hardy DB, Kovaric K, Mendelson CR. Up-regulation of the progesterone receptor (PR)-C isoform in laboring myometrium by activation of nuclear factor-kappaB may contribute to the onset of labor through inhibition of PR function. Mol Endocrinol. 2006;20:764-75.

55. Lim R, Lappas M. Differential expression of AP-1 proteins in human myometrium after spontaneous term labour onset. Eur J Obstet Gynecol Reprod Biol. 2014;177:100-5.

56. Mitchell JA, Lye SJ. Differential expression of activator protein-1 transcription factors in pregnant rat myometrium. Biol Reprod. 2002;67:240-6.

57. Serfling E, Berberich-Siebelt F, Avots A, Chuvpilo S, Klein-Hessling S, Jha MK, et al. NFAT and NF-kappaB factors-the distant relatives. Int J Biochem Cell Biol. 2004;36:1166-70.

58. Pham LV, Tamayo AT, Yoshimura LC, Lin-Lee YC, Ford RJ. Constitutive NF-kappaB and NFAT activation in aggressive B-cell lymphomas synergistically activates the CD154 gene and maintains lymphoma cell survival. Blood. 2005;106:3940-7.

59. Fu L, Lin-Lee YC, Pham LV, Tamayo A, Yoshimura L, Ford RJ. Constitutive NF-kappaB and NFAT activation leads to stimulation of the BLyS survival pathway in aggressive B-cell lymphomas. Blood. 2006;107:4540-8.
60. Ding J, Wu K, Zhang D, Luo W, Li J, Ouyang W, et al. Activation of both nuclear factor of activated $T$ cells and inhibitor of nuclear factor-kappa B kinase beta-subunit-/nuclear factor-kappa B is critical for cyclooxygenase-2 induction by benzo[a]pyrene in human bronchial epithelial cells. Cancer Sci. 2007;98:1323-9.

61. Cai T, Ding J, Luo W, Li J, Huang C. A cross-talk between NFAT and NF-kB pathways is crucial for nickel-induced COX expression in Beas-2B cells. Curr Cancer Drug Targets. 2011;11:548-59.

\section{Submit your next manuscript to BioMed Central and take full advantage of:}

- Convenient online submission

- Thorough peer review

- No space constraints or color figure charges

- Immediate publication on acceptance

- Inclusion in PubMed, CAS, Scopus and Google Scholar

- Research which is freely available for redistribution 